\title{
Genetic Diversity and Acquired Drug Resistance Mutations Detected by Deep Sequencing in Virologic Failures Among Antiretroviral Treatment Experienced Human Immunodeficiency Virus-I Patients in a Pastoralist Region of Ethiopia [Corrigendum]
}

\author{
Tachbele E, Kyobe S, Katabazi FA, et al. Infect Drug \\ Resist. 2021;14:4833-4847.
}

The authors have advised affiliation 4 on page 4833 is incorrect. The correct affiliation should read "J. Craig Venter Institute, Rockville, MD, USA".
Infection and Drug Resistance

\section{Publish your work in this journal}

Infection and Drug Resistance is an international, peer-reviewed openaccess journal that focuses on the optimal treatment of infection (bacterial, fungal and viral) and the development and institution of preventive strategies to minimize the development and spread of resistance. The journal is specifically concerned with the epidemiology of
Rembert Pieper was not affiliated with Janssen Biopharma, South San Francisco, CA, USA, when the work was conducted. It is their current affiliation and should have only been noted as an acknowledgment. The authors apologize for this error. antibiotic resistance and the mechanisms of resistance development and diffusion in both hospitals and the community. The manuscript management system is completely online and includes a very quick and fair peerreview system, which is all easy to use. Visit http://www.dovepress.com/ testimonials.php to read real quotes from published authors. 